\title{
Analisis Faktor Determinan Peningkatan Partisipasi Politik Penyandang Disabilitas pada Pilkada Kota Yogyakarta 2017
}

\author{
Pangky Febriantanto ${ }^{1}$
}

\begin{abstract}
Abstrak
Pada pilkada kota Yogyakarta 2017 terdapat peningkatan partisipasi pemilih penyandang disabilitas. Selain itu, penyandang disabilitas juga terlibat dalam setidaknya tiga kali diskusi politik yang merupakan peningkatkan partisipasi politik penyandang disabilitas. Penyandang disabilitas juga terlibat dalam kegiatan pemantauan pilkada kota Yogyakarta 2017 di bawah bendera LSM. Hal-hal tersebut merupakan peningkatan partisipasi politik pemilih penyandang disabilitas. Peningkatan tersebut dapat diteliti dengan menganalisis faktor determinannya. Metode penelitian menggunakan pendekatan deskriptif kualitatif yang menggunakan data utama dari KPU kota Yogyakarta, Panwaslu kota Yogyakarta, penyandang disabilitas, serta kelompok komunitas. Data pendukung juga didapat dari laporan hasil pelaksanaan dan pemantauan pilkada kota Yogyakarta 2017. Hasil penelitian menunjukkan bahwa ada empat dari lima faktor pendukung peningkatan partisipasi politik penyandang disabilitas pilkada kota Yogyakarta 2017 berdasarkan teori Milbrath, seperti faktor pendidikan politik seperti masifnya sosialisasi oleh penyelenggara pilkada, faktor perangsang politik seperti pelibatan penyandang disabilitas dalam diskusi, faktor situasi atau lingkungan politik seperti pengaruh tokoh yang juga seorang penyandang disabilitas, dan faktor karakteristik pribadi seperti kemauan penyandang disabilitas untuk terlibat dalam pilkada kota Yogyakarta 2017. Sedangkan faktor karakteristik sosial seperti status ekononomi, ras, etnis, dan agama penyandang disabilitas tidak menjadi faktor pendukung. Dari hal tersebut juga dapat ditarik argumen bahwa karakteristik sosial tidak banyak berpengaruh pada persepsi dan perilaku penyandang disabilitas dalam berpartisipasi dalam pilkada kota Yogyakarta 2017.
\end{abstract}

Kata Kunci: Partisipasi; Penyandang Disabilitas; Pilkada; Kota Yogyakarta

1 Pangky Febriantanto adalah alumnus Fakultas Ilmu Sosial dan Ilmu Politik Universitas Gadjah Mada dan Magister Ilmu Pemerintahan Unversitas Muhammadiyah Yogyakarta, serta dosen di SF Global Education Kulon Progo, Yogyakarta. 


\section{Pendahuluan}

Tulisan ini membahas tentang peningkatan partisipasi politik penyandang disabilitas pada pilkada kota Yogyakarta 2017. Menurut Almond dalam Mas'oed (2011), pemberian suara dalam pemilu, diskusi politik, serta bergabung dengan kelompok kepentingan merupakan bentuk-bentuk dari partisipasi politik konvensional. Dari segi pemberian suara, terdapat peningkatan partisipasi pemilih dari sebesar 66,5\% pada pemilihan umum 2014 di kota Yogyakarta menjadi 70,9\% pada pillkada kota Yogyakarta 2017. Selain itu, juga terdapat partisipasi poltik penyandang disabilitas dalam tiga diskusi politik. Yang pertama adalah diskusi tentang "Validasi Data Pemilih Penyandang Disabilitas", kemudian diskusi politik "Jogja Gumregah Menuju Pesta Demokrasi Akuntabel, Transparan, dan Berintegritas”, serta diskusi politik bertema "Politik Difabel". Penyandang disabilitas juga terlibat dalam pemantauan pilkada kota Yogyakarta 2017 di bawah bendera LSM NARASITA yang bertugas memantau pelaksanaan pemungutan suara di TPS-TPS pada 15 Februari 2017 di kota Yogyakarta dan kabupaten Kulon Progo.

Adanya peningkatan partisipasi politik tersebut diteliti dengan menganalisis faktor-faktor determinannya berdasarkan teori pendukung partisipasi politik dari Milbrath. Dari kelima faktor pendukung partisipasi politik menurut Milbrath, satu demi satu faktor dibedah kontribusinya dalam meningkatkan partisipasi politik penyandang disabilitas pada pilkada kota Yogyakarta 2017. Dari pembahasan kelima faktor pendukung partisipasi politik akan diketahui faktor mana yang paling mendukung peningkatan partisipasi politik penyandang disabilitas dan faktor mana yang tidak memberi dukungan dalam peningkatan politik pemilih penyandang disabilitas. Dengan demikian, diharapkan tulisan ini mampu memberi kontribusi positif yang bermanfaat bagi dunia akademis sebagai salah satu bahan kajian kepemiluan. Selain itu, tulisan ini juga memberi kontribusi 
positif bagi penyelenggara pemilihan umum selain sebagai bahan evaluasi pilkada kota Yogyakarta 2017, juga sebagai bahan penyusunan agenda kebijakan dan bahan formulasi kebijakan. Nantinya dari tulisan ini, Komisi Pemilihan Umum dapat membuat kebijakan-kebijakan yang dapat mempertahankan atau bahkan memperkuat faktor-faktor yang menjadi pendukung peningkatan partisipasi politik termasuk pemilih, khususnya pemilih penyandang disabilitas.

Adapun tema mengenai partisipasi dalam pemilihan umum termasuk pemilihan kepala daerah perlu dibahas karena salah satu hal yang dapat dijadikan ukuran kualitas pemilihan umum adalah angka partisipasi pemilih atau angka pengguna hak pilih, yangmana partisipasi pemilih termasuk dalam partisipasi politik. Selain itu, tingginya jumlah partisipasi pemilih selain sebagai ajang melaksanakan kedaulatan rakyat untuk memperkuat hail pemilihan umum yang legitimate, tingginya partisipasi pemilih juga merupakan penanda kepedulian warga negara demokratis. Sedangkan rendahnya partisipasi pemilih atau pengguna hak pilih merupakan indikasi adanya apatisme dan ketidakpercayaan warga negara terhadap proses politik.

Tema mengenai partisipasi politik, khususnya partisipasi pemilih penyandang disabilitas juga perlu dibahas karena berdasarkan peraturan perundang-undangan ditegaskan bahwa setiap warga negara berhak terlibat aktif dalam kehidupan berpolitik, termasuk warga penyandang disabilitas. Dengan tulisan ini, diharapkan menjadi salah satu barometer tentang apakah penyandang disabilitas sebagai bagian warga negara sudah mendapatkan kesempatan yang sama dalam pemilihan umum, baik untuk dipilih maupun memilih tanpa diskriminasi?

Kota Yogyakarta dipilih dalam lokus penelitian tulisan ini dikarenakan kota Yogyakarta menjadi salah satu kota yang patut menjadi perhatian dalam kaitannya dengan hak penyandang disabilitas dalam pemilihan umum. Tahun 2014, KPU kota Yogyakarta mendapat 
penghargaan dari KPU Republik Indonesia untuk kategori pemilu akses tahun 2014. Selain itu, KPU kota Yogyakarta juga mendapat penghargaan dari KPU DIY sebagai juara 1 kategori pemilu akses. Penghargaan tersebut diberikan kepada KPU kota Yogyakarta atas upayanya dalam mewujudkan pemilihan umum tahun 2014 yang lebih ramah difabel.

Upaya yang telah dilakukan oleh KPU kota Yogyakarta pada pemilihan umum 2014 berupa mempersiapkan sarana aksesibel yang spesifik bagi pemilih penyandang disabilitas jenis tertentu, seperti pembuatan Daftar Calon Tetap (DCT) braille untuk DPRD kota Yogyakarta, dan pembuatan template untuk DPRD kota Yogyakarta dan DPR RI untuk dapil DIY. Yang paling menjadi perhatian adalah tingkat partisipasi penyandang disabilitas dalam menggunakan hak pilihnya yang cukup tinggi.

Tingkat partisipasi pemilih penyandang difabel yang menggunakan hak pilihnya dalam pemilu 2014 di kota Yogyakarta adalah sebesar $66,5 \%$. Hal tersebut sesuai dengan hasil penelitian program kreativitas mahasiswa Universitas Muhammadiyah Yogyakarta tahun 2015 yang kemudian menjadi skripsi yang ditulis oleh Agus Andika Putra dengan judul “Tingkat Partisipasi Penyandang Disabilitas pada Pemilu 2014 di Kota Yogyakarta", yang menyebutkan bahwa partisipasi penyandang disabilitas pada pemilu 2014 adalah 66,5\%. Pada pemilu 2014, jumlah daftar pemilih penyandang disabilitas kota Yogyakarta adalah sejumlah 268 orang. Artinya, 178 orang penyandang disabilitas di antaranya menggunakan hak pilihnya dan hanya 90 orang penyandang disabilitas yang tidak menggunakan hak pilihnya.

Sedangkan dalam pilkada kota Yogyakarta tahun 2017, tercatat ada 494 penyandang disabilitas dari 298.989 orang dalam DPT. Hasil pilkada kota Yogyakarta 2017 kemudian diketahui bahwa dari 494 penyandang disabilitas, 350 di antaranya menggunakan hak pilihnya. 
Hasil pilkada kota Yogyakarta tahun 2017 tersebut menunjukkan bahwa angka partisipasi pemilih penyandang disabilitas meningkat dibanding dengan hasil pemilu terakhir tahun 2014. Hasil pilkada kota Yogyakarta 2017 tercatat ada 350 dari 494 penyandang disabilitas yang tercatat dalam DPT yang menggunakan hak pilihnya. Artinya, persentase penyandang disabilitas yang tercatat dalam DPT yang menggunakan hak pilihnya pada pilkada kota Yogyakarta 2017 mencapai 70,9\%. ${ }^{2}$

\section{Kerangka Teori}

Berangkat dari latar belakang tersebut, maka untuk mempermudah penulisan penelitian, diambil kerangka teori sebagai batasan fokus pembahasan. Kerangka teori yang relevan dengan latar belakang serta fokus penulisan adalah teori tentang pemilihan kepala daerah yang merupakan salah satu jenis pemilihan umum, teori tentang penyandang disabilitas, dan teori tentang partisipasi politik.

\section{Pemilihan Umum}

Pemilihan umum atau pemilu merupakan suatu wujud nyata dari demokrasi dan menjadi sarana bagi rakyat dalam menyatakan kedaulatannya terhadap negara dan pemerintah. Kedaulatan rakyat dapat diwujudkan dalam proses pemilu untuk menentukan siapa yang harus menjalankan dan mengawasi pemerintahan dalam suatu negara. Dengan adanya pemilu, maka kedaulatan rakyat sebagai perwujudan hak asas politik rakyat telah dilaksanakan. Selain itu, adanya pemilu terbukti bahwa pergantian pemerintahan secara aman, damai, dan tertib terlaksana, serta kesinambungan pembangunan nasional menjadi terjamin.

2 Eka Arifa Rusqiyati. (2017). Tingkat Partisipasi Pemilih Yogyakarta Capai Target. Https:// jogja.antaranews.com/berita/344965/tingkat-partisipasi-pemilih-yogyakarta-capai-target. Diakses 10 April 2018. 
Hal tersebut sejalan dengan pendapat Haryanto dalam Miriam Budiardjo (1998) yang menyatakan bahwa:

"Pemilihan umum merupakan kesempatan bagi para warga negara untuk memilih pejabat-pejabat pemerintah dan memutuskan apakah yang mereka inginkan untuk dikerjakan oleh pemerintah dan dalam membuat keputusan itu para warga negara menentukan apakah yang sebenarnya yang mereka inginkan untuk dimiliki."

Menurut Gaffar (Efrizal, 2012), pemilu adalah sarana utama mewujudkan demokrasi dalam suatu negara. Substansi pemilu adalah penyampaian suara rakyat untuk membentuk lembaga perwakilan dan pemerintahan sebagai penyelenggara negara. Suara rakyat diwujudkan dalam bentuk hak pilih, yaitu hak untuk memilih wakil dari berbagai calon yang ada.

Menurut Efrizal (2012), pemilu merupakan cara yang terkuat bagi rakyat untuk berpartisipasi di dalam sistem demokrasi perwakilan modern. Dari berbagai pendapat di atas dapat disimpulkan bahwa pemilihan umum adalah sarana demokrasi untuk membentuk suatu sistem kekuasaan negara yang lahir dari rakyat dan menurut kehendak rakyat yang dipraktikkan dalam bentuk perwakilan, di dalamnya terdapat kompetisi politik adil dan terbuka dalam pelaksanaannya.

Adapun macam-macam pemilihan umum antara lain pemilihan presiden dan wakil presiden; pemilihan umum legislatif, yang terdiri dari pemilihan umum Dewan Perwakilan Rakyat (DPR), Dewan Perwakilan Daerah (DPD), Dewan Perwakilan Rakyat Daerah (DPRD) provinsi, dan Dewan Perwakilan Rakyat Daerah (DPRD) kabupaten atau kota; serta pemilihan kepala daerah, baik itu pemilihan gubernur dan wakil gubernur, walikota dan wakil walikota, maupun bupati dan wakil bupati. 


\section{Pemilihan Kepala Daerah}

Pemilihan kepala daerah atau pilkada adalah upaya demokrasi untuk mencari pemimpin daerah, baik itu tingkat provinsi maupun tingkat kota dan kabupaten sesuai dengan asas pemilihan umum yang langsung, umum, bebas, rahasia, jujur, dan adil. Dengan kata lain, pilkada adalah pemilihan umum yang terbatas hanya untuk memilih kepala dan wakil kepala lingkup eksekutif pada kurang lebih 33 provinsi, kecuali provinsi Daerah Istimewa Yogyakarta. Juga untuk memilih kepala dan wakil kepala lingkup eksekutif pada lebih dari 500 kabupaten dan kota, kecuali kabupaten Kepulauan Seribu, kota Jakarta Pusat, kota Jakarta Selatan, kota Jakarta Barat, kota Jakarta Timur, dan kota Jakarta Utara yang merupakan kabupaten dan kota administrasi yang berada di provinsi Daerah Khusus Ibukota Jakarta.

Gubernur dan wakil gubernur pada pilkada dipilih sebagai pasangan untuk masa jabatan lima tahun dengan sistem suara terbanyak atau mayoritas suara, kecuali pilkada provinsi DKI Jakarta yang harus memperoleh minimal 50\% ditambah satu suara sah. Jika mayoritas relatif ini tidak tercapai, putaran kedua antara dua kandidat yang memperoleh suara terbesar akan diselenggarakan. Sedangkan pilkada kabupaten atau kota yang menjadi kepala eksekutif sebuah kabupaten adalah bupati, dan kepala eksekutif sebuah kota adalah walikota. Gubernur, bupati atau walikota, beserta wakilnya, dipilih sebagai pasangan untuk periode masa jabatan lima tahun.

Pemilihan kepala daerah dan wakil kepala daerah, baik gubernur dan wakil gubernur maupun bupati atau walikota dan wakil bupati atau wakil walikota secara langsung merupakan perwujudan pengembalian hak-hak dasar dalam memilih pemimpin di daerah. Dengan demikian, rakyat memiliki kesempatan dan kedaulatan untuk menentukan pemimpin daerah secara langsung, bebas, dan rahasia tanpa adanya intervensi sama halnya mereka memilih presiden dan wakil presiden dan wakil-wakilnya di legislatif dalam pemilu (Joko J. Prihatmoko, 
2005).

Salah satu ciri sistem pilkada yang demokratis dapat dilihat dari asas-asas yang dianut. Asas adalah suatu pangkal tolak pikiran untuk suatu kasus atau suatu jalan dan sarana untuk menciptakan sesuatu tata hubungan atau kondisi yang kita kehendaki. Asas pilkada adalah pangkal tolak pikiran untuk melaksanakan pilkada. Dengan kata lain, asas pilkada merupakan prinsip-prinsip atau pedoman yang harus mewarnai proses penyelenggaraan. Asas pilkada juga berarti jalan atau saran agar agar pilkada terlaksanakan secara demokratis (Joko J. Prihatmoko, 2005).

Lebih lanjut, Joko J. Prihatmoko (2005) menjabarkan mengenai pengertian asas-asas tersebut, yaitu langsung, umum, bebas, rahasia, jujur, dan adil. Langsung berarti rakyat sebagai pemilih mempunyai hak untuk memberikan suaranya secara langsung sesuai dengan kehendak hati nuraninya, tanpa perantara. Umum artinya pada dasarnya semua warga negara yang memenuhi persyaratan sesuai dengan ketentuan perundangan berhak mengikuti pilkada. Pemilihan yang bersifat umum mengandung makna menjamin kesempatan yang berlaku menyeluruh bagi semua warga negara tanpa diskriminasi berdasarkan suku, agama, ras, golongan, jenis kelamin, kedaerahan, pekerjaan, dan status sosial. Bebas artinya setiap warga negara berhak memilih secara bebas menentukan pilihan tanpa tekanan dan paksaan dari siapa pun. Rahasia artinya dalam memberikan suaranya, pemilih dijamin dan pilihannya tidak akan diketahui oleh pihak mana pun dan dengan jalan apa pun. Jujur artinya dalam penyelenggaraan pilkada, setiap penyelenggara pilkada harus bersikap dan bertindak jujur sesuai dengan peraturan perundang-undangan. Dan adil artinya dalam penyelenggaraan pilkada, setiap pemilih dan calon/peserta pilkada mendapat perlakuan yang sama, serta bebas dari kecurangan pihak mana pun. 


\section{Partisipasi Politik}

Partisipasi adalah penentuan sikap dan keterlibatan hasrat setiap individu dalam situasi dan kondisi organisasinya, sehingga pada akhirnya mendorong individu tersebut berperan serta dalam pencapaian tujuan organisasi, serta ambil bagian dalam setiap pertanggungjawaban bersama. ${ }^{3}$ Sastroatmodjo (1995) juga berpendapat bahwa partisipasi politik pada dasarnya merupakan kegiatan yang dilakukan warga negara untuk terlibat dalam proses pengambilan keputusan dengan tujuan untuk memengaruhi pengambilan keputusan yang dilakukan pemerintah.

Herbert McClosky, seorang tokoh masalah partisipasi dalam International Encyclopedia of the Social Sciences, Edisi Kedua, 1972, sebagaimana dikutip Miriam Budiardjo menegaskan:

"Partisipasi politik adalah kegiatan-kegiatan sukarela dari warga masyarakat melalui mana mereka mengambil bagian dalam proses pemilihan penguasa, dan secara langsung atau tidak langsung dalam proses pembentukan kebijakan umum."

(The term 'political participation' will refer to those voluntary activities by which members of a society share in the selection of rulers and, directly or indirectly, in the formation of public policy). ${ }^{4}$

Sedangkan Miriam Budiarjo (Sasrtoatmodjo, 1995) mendefinisikan partisipasi politik adalah kegiatan seseorang atau kelompok orang untuk ikut serta secara aktif dalam kehidupan politik, yaitu dengan jalan memilih pimpinan negara dan secara langsung atau tidak langsung memengaruhi kebijakan pemerintah. Dari berbagai pengertian

3 Arifin Rahman. (2002). Sistem Politik Indonesia Dalam Perspektif Struktural Fungsional. Surabaya: SIC.

4 Miriam Budiardjo. (2008). Dasar-dasar Ilmu Politik. Jakarta: Gramedia Pustaka Utama. 
mengenai partisipasi politik tersebut, dapat diambil kesimpulan bahwa yang dimaksud partisipasi politik adalah keterlibatan individu atau kelompok sebagai warga negara dalam proses politik yang berupa kegiatan yang positif dan dapat juga yang negatif yang bertujuan untuk berpartisipasi aktif dalam kehidupan politik. Apabila dikaitkan dengan pemilu sebagai kegiatan politik, maka partisipasi pemilih dikatakan bahwa keterlibatan individu atau kelompok sebagai warga negara bertujuan untuk memberikan hak suaranya dalam pemilu. Hal tersebut sesuai dengan partisipasi politik yang dikemukakan oleh Almond (Masoed, 2011) yang menerangkan bahwa pemberian suara dalam pemilu juga pilkada termasuk dalam salah satu bentuk partisipasi politik, khususnya partisipasi politik konvensional. Lebih lanjut, Almond (Mas'oed, 2011) membedakan bentuk partisipasi politik, yaitu partisipasi politik konvensional dan nonkonvensional. Bentuk partisipasi politik konvensional merupakan bentuk yang lazim dan dapat berupa pemberian suara, diskusi politik, kegiatan kampanye, bergabung dengan kelompok kepentingan, maupun komunikasi individu dengan pejabat politik administratif. Sedangkan bentuk partisipasi nonkonvensional merupakan bentuk yang tidak lazim berupa pengajuan petisi berdemonstrasi, konfrontasi, mogok, maupun tindak kekerasan politik.

Kemudian, Milbrath (Maran, 2007) menyebutkan bahwa dua faktor utama yang mendorong orang berpartisipasi politik adalah adanya faktor pendukung dan faktor penghambat. Di dalam faktor pendukung tersebut, terdapat lima unsur: perangsang politik, karakteristik pribadi seseorang, karakteristik sosial, situasi atau lingkungan politik, dan pendidikan politik. Adapun faktor pertama, faktor perangsang politik adalah suatu dorongan terhadap seorang pemilih agar mau berpatisipasi dalam kehidupan politik. Artinya, orang bersedia berpartisipasi dalam kehidupan politik menerima perangsang politik. Perangsang politik dipengaruhi oleh kegiatan diskusi politik, pengaruh media massa, dan 
diskusi-diskusi formal dan informal. Kemudian, faktor kedua adalah faktor karakteristik pribadi seseorang. Faktor ini merupakan faktor dimana watak sosial seorang pemilih yang mempunyai kepedulian sosial yang besar terhadap berbagai masalah. Orang-orang yang berwatak sosial yang mempunyai kepedulian sosial yang besar terhadap masalah sosial, politik, ekonomi, sosial budaya, dan pertahanan keamanan, biasanya bersedia terlihat dalam aktivitas politik.

Faktor ketiga adalah faktor karakteristik sosial yang merupakan faktor status sosial, ekonomi, kelompok ras, etnis, dan agama seseorang yang akan memengaruhi persepsi, sikap, dan perilaku seseorang dalam beraktivitas. Bagaimanapun juga, karakteristik sosial ikut memengaruhi persepsi dan sikap perilaku seseorang dalam bidang politik. Oleh sebab itulah, orang bersedia berpartisipasi dalam bidang politik. Faktor keempat adalah faktor situasi atau lingkungan politik yang merupakan faktor dimana keadaan lingkungan sosial sekitar seorang pemilih yang baik dan kondusif agar seorang pemilih mau dengan senang hati berpartisipasi dalam aktivitas politik. Di lingkungan politik yang demokratis, orang merasa lebih bebas dan nyaman untuk terlibat dalam aktivitas-aktivitas politik daripada dalam lingkungan politik yang otoriter. Lingkungan politik yang sering diisi dengan aktivitas-aktivitas brutal dan kekerasan dengan sendirinya menjauhkan masyarakat dari wilayah politik. Dan, faktor kelima adalah faktor pendidikan politik yang merupakan upaya pemerintah untuk merubah warga negara agar dapat memiliki kesadaran politik dengan terlibat dalam aktivitas politik.

Selain faktor pendukung, Milbrath (Maran, 2007) juga menyebutkan tiga faktor yang dapat menjadi panghambat suatu partisipasi politik. Adapun faktor penghambat dari partisipasi politik itu antara lain kebijakan induk organisasi selalu berubah, pemilih pemula yang otonom, dan dukungan yang kurang dari induk organisasi dalam rangka menyukseskan kegiatan politik. Maksud dari kebijakan 
induk selalu berubah adalah organisasi atau badan yang dipandang elite politik dalam tubuh suatu organisasi masyarakat atau seorang pemilih selalu mengubah kebijakan terhadap partisipasi yang ada dengan yang baru sesuai situasi dan kondisi. Kemudian, pemilih pemula yang otonom akan membuat gerakan politisnya tidak independen, dan berada dalam hubungan suatu organisasi induknya, baik sifatnya konsultasi maupun koordinasi. Terakhir adalah dukungan yang kurang dari induk organisasi dalam menyukseskan kegiatan politik. Apabila terdapat dukungan yang kurang selama proses partisipasi politik, maka akan menghambat aktivitas politik pemilih.

Berdasarkan pendapat di atas, dalam partisipasi politik juga terdapat faktor penghambat yang bisa membuat seseorang tidak berpartisipasi dalam kegiatan politik, yaitu kebijakan induk organisasi yang selalu berubah, pemilih pemula yang otonom, dan dukungan yang kurang dari induk organisasi dalam menyuksekan kegiatan politik. Dengan tiga faktor itu, seseorang dapat menjadi tidak berpartisipasi politik dalam kegiatan politik seperti pemilu.

\section{Penyandang Disabilitas}

Berdasarkan laporan ESCAP (The Economic and Social Commission for Asia and the Pasific) bahwa setiap negara memiliki definisinya sendiri tentang disabilitas. Keragaman definisi membuat organisasi internasional seperti Disabled People's International (DPI) memutuskan untuk tidak mengadopsi atau membuat definisi guna menghindari kemungkinan terjadinya perselisihan dengan pihak lain. Namun, kini terjadi perkembangan transisi dalam memandang disabilitas dari model medis ke model sosial. Model medis memandang disabilitas sebagai masalah kesehatan, sementara model sosial memandang disabilitas sebagai hasil dari interaksi sosial. Kedua model ini tidak dapat didefinisikan secara terpisah karena disabilitas juga berakar dari dan memengaruhi kondisi kesehatan seseorang. Kedua model ini 
saling melengkapi. ${ }^{5}$

Namun, World Health Organization (WHO) yang merupakan sebuah organisasi kesehatan dunia yang bernaung di bawah United Nations (UN) atau Persyarikatan Bangsa-bangsa (PBB) memiliki definisi sendiri mengenai disabilitas. Menurut WHO, disabilitas diartikan sebagai: ${ }^{6}$

"Istilah umum yang memiliki gangguan fungsi tubuh atau struktur, keterbatasan aktivitas, dan pembatasan partisipasi. Dalam hal ini meliputi gangguan dalam fungsi tubuh atau struktur, pembatasan kegiatan adalah kesulitan yang dihadapi oleh individu dalam melaksanakan tugas atau tindakan. Sedangkan pembatasan partisipasi adalah masalah yang dialami oleh seseorang individu dalam keterlibatannya dalam kehidupan sehari-hari. Jadi, disabilitas adalah fenomena yang kompleks yang mencerminkan interaksi antara bagian tubuh seseorang dan bagian dari masyarakat dimana dia tinggal."

Di Indonesia, menurut Undang-undang Nomor 8 Tahun 2016 tentang Penyandang Disabilitas, penyandang disabilitas adalah setiap orang yang mengalami keterbatasan fisik, intelektual, mental, dan/ atau sensorik dalam jangka waktu lama yang dalam berinteraksi dengan lingkungan dapat mengalami hambatan dan kesulitan untuk berpartisipasi secara penuh dan efektif dengan warga negara lainnya berdasarkan kesamaan hak. Ragam penyandang disabilitas menurut Undang-undang Nomor 8 Tahun 2016 meliputi penyandang disabilitas fisik, penyandang disabilitas intelektual, penyandang disabilitas mental,

5 General Election Network For Disability Acces. Sekilas Tentang Disabilitas. 2017. http:// www2.agendaasia.org/index.php/id/informasi/sekilas-tentang-disabilitas/102-sekilastentang-disabilitas. diakses 10 April 2018

6 Disabled World. Definitions of Disability. http://www.disabledworld.com/definitions/ disability-definitions.php. Diakses 10 April 2018. 
dan/atau penyandang disabilitas sensorik. Meskipun demikian, dalam pilkada kota Yogyakarta 2017, pendataan ragam penyandang disabilitas terbagi dalam lima jenis yang meliputi disabilitas netra, disabilitas daksa, disabilitas rungu dan wicara, disabilitas grahita, dan disabilitas lainnya. Sedangkan menurut Vash (1981), ada perbedaan antara kata disability, yaitu mengacu pada adanya kekurangan secara fisiologis; anatomis psikologis yang disebabkan oleh luka, kecelakaan, maupun cacat sejak lahir dan cenderung menetap. Dari berbagai definisi tersebut, dapat dikatakan bahwa difabel atau penyandang disabilitas adalah orang yang memiliki keterbatasan fisik maupun nonfisik yang berbeda dengan orang lain yang berdampak pada hambatan. Istilah penyandang disabilitas juga sering dikaitkan dengan orang yang berkebutuhan khusus. Hal itu dikarenakan penyandang disabilitas membutuhkan sesuatu yang khusus, tergantung jenis disabilitasnya.

Sedangkan Peter (2007) yang juga merujuk pada definisi penyandang disabilitas menurut WHO, mengemukakan penyandang disabilitas yang berbasis pada model sosial. Penyandang disabilitas yang berbasis pada model sosial adalah impairment atau kerusakan atau kelemahan, dan disability atau handicap yang dapat diartikan sebagai ketidakmampuan. Impairment yaitu ketidaklengkapan atau ketidaknormalan yang disertai akibatnya terhadap fungsi tertentu. Misalnya, kelumpuhan di bagian bawah tubuh disertai ketidakmampuan untuk berjalan dengan kaki. Sedangkan disability atau handicap, yaitu sebuah atau beberapa kerugian serta keterbatasan dalam aktivitas tertentu sebagai akibat faktor-faktor sosial yang hanya sedikit atau sama sekali tidak memperhitungkan orang-orang yang menyandang kelemahan tertentu dan karenanya mengeluarkan orang-orang itu dari arus aktivitas sosial.

Disability Discrimination Act (DDA) menyatakan kriteria-kriteria untuk sebutan penyandang disabilitas adalah mereka yang memiliki gangguan mental atau fisik. Gangguan tersebut memiliki efek yang 
buruk pada kemampuan mereka untuk melaksanakan kegiatan normal sehari-hari. Gangguan tersebut memiliki efek samping yang substansial dan jangka panjang (telah berlangsung selama 12 bulan atau lebih atau selama sisa hidup seseorang). ${ }^{7}$

\section{Partisipasi Politik Penyandang Disabilitas}

Penyandang disabilitas memiliki hak untuk terlibat aktif dalam politik atau berpartisipasi dalam politik. Penyandang disabilitas sebagai bagian dari warga negara juga berhak mendapat kesempatan yang sama dalam pemilu, baik untuk dipilih maupun memilih tanpa diskriminasi. Artinya, penyandang disabilitas diberi kesempatan yang sama untuk mengapresiasikan hak-hak dasar, termasuk hak politik seperti hak pilih dalam pemilu.

Hal tersebut sesuai dengan Undang-undang Nomor 8 Tahun 2016 tentang Penyandang Disabilitas yang menyebutkan bahwa:

\section{"Negara Kesatuan Republik Indonesia menjamin kelangsungan hidup setiap warga negara, termasuk para penyandang disabilitas yang mempunyai kedudukan hukum dan memiliki hak asasi manusia yang sama sebagai Warga Negara Indonesia dan sebagai bagian tidak terpisahkan dari warga negara dan masyarakat Indonesia merupakan amanah dan karunia Tuhan Yang Maha Esa, untuk hidup maju dan berkembang secara adil dan bermartabat."}

Dalam Undang-undang Nomor 8 Tahun 2016, Pasal 5 Ayat 1 huruf $\mathrm{h}$ juga menyatakan bahwa penyandang disabilitas juga memiliki hak untuk berpartisipasi dalam politik. Hak tersebut juga sudah diamanatkan dalam Pasal 13 yang menyatakan bahwa hak politik penyandang disabilitas salah satunya adanya memilih dan dipilih dalam jabatan publik. Serta memilih partai politik dan/atau peserta individu

7 Disabled World. Definitions of Disability. Http://www.disabledworld.com/definitions/ disability-definitions.php. Diakses 10 April 2018. 
yang menjadi peserta dalam pemilu juga merupakan salah satu bentuk partisipasi penyandang disabilitas dalam memberikan hak politiknya.

Di kota Yogyakarta, khususnya pada pilkada kota Yogyakarta 2017, partisipasi poltik penyandang disabilitas secara garis besar dapat dilihat pada "Skripsi” UIN Sunan Kalijaga tahun 2017 yang ditulis oleh Metty Sinta Oppyfia dengan judul "Pemenuhan Hak Politik Difabel Pilkada Kota Yogyakarta Tahun 2017 dengan studi implementasi UU No. 8 Tahun 2016". Dalam skripsi tersebut, disebutkan bahwa implementasi Undang-undang Nomor 8 Tahun 2016 dalam pilkada kota Yogyakarta 2017 sudah sesuai dengan prinsip musyawarah dan prinsip keadilan sosial melalui pendidikan politik, sosialisasi, dan simulasi pelaksanaan pilkada kepada pemilih difabel. Prinsip kebebasan diwujudkan melalui penggunaan teknologi braille template untuk pemilih difabel netra, TPS akses untuk pemilih difabel daksa, dan informasi visual serta pendamping pemilih untuk difabel rungu. Dari skripsi tersebut, telah disebutkan bahwa partisipasi politik penyandang disabilitas pada pilkada kota Yogyakarta 2017 sudah terlaksana melalui pendidikan politik, sosialisasi, dan simulasi pelaksanaan pilkada kepada pemilih difabel.

Kemudian, dalam tesis Universitas Airlangga tahun 2017 yang ditulis oleh I Gusti Gede Made Gustem Lasida dengan judul "Membangun Pemilu Inklusif untuk Difabel dengan Studi Kasus Pilwali Kota Yogyakarta 2017" disebutkan bahwa pada pilwali (pilkada) kota Yogyakarta 2017 sebetulnya penyandang disabilitas sudah dilibatkan dalam pilwali kota Yogyakarta sebagai relawan demokrasi dan dalam simulasi TPS. Meski demikian, penyelenggara pemilu perlu menjalin kerja sama yang baik dengan organisasi difabel dalam berbagai lini sehingga dapat mengambil kebijakan yang berpihak pada difabel dan menghasilkan solusi meningkatkan pemilu inklusif. Dari tesis tersebut telah terlihat adanya partisipasi poltik difabel, yaitu pada pelibatan difabel khususnya pada simulasi TPS. 
Dari penelitian skripsi dan tesis di atas, dapat dikatakan bahwa partisipasi politik penyandang disabilitas pada pilkada kota Yogyakarta 2017 sudah terlaksana. Khususnya, partisipasi politik dalam hal pendidikan politik, sosialisasi, serta simulasi pemungutan suara. Lalu, bagaimana dengan partisipasi pemilih penyandang disabilitas dalam pilkada kota Yogyakarta 2017? Dalam pilkada kota Yogyakarta 2017, partisipasi politik penyandang disabilitas dapat dilihat dari partisipasi politik secara konvensional menurut Almond. Partisipasi politik yang pertama dan paling utama yang dapat terlihat adalah pemberian suara atau partisipasi pemilih penyandang disabilitas yang menggunakan hak pilihnya dalam pemungutan suara pada pilkada kota Yogyakarta 2017. 
Tabel 1. Persentase Pengguna Hak Pilih Penyandang Disabilitas Pilkada Kota Yogyakarta 2017

\begin{tabular}{|c|c|c|c|}
\hline Kecamatan & $\begin{array}{c}\text { Pemilih } \\
\text { Penyandang } \\
\text { Disabilitas }\end{array}$ & $\begin{array}{l}\text { Pengguna } \\
\text { Hak Pilih } \\
\text { Penyandang } \\
\text { Disabilitas }\end{array}$ & $\begin{array}{c}\text { Persentase } \\
\text { Pengguna Hak } \\
\text { Pilih Penyandang } \\
\text { Disabilitas }\end{array}$ \\
\hline Danurejan & 28 & 22 & $78,6 \%$ \\
\hline Gedongtengen & 22 & 16 & $72,7 \%$ \\
\hline Gondokusuman & 68 & 43 & $63,2 \%$ \\
\hline Gondomanan & 29 & 17 & $58,6 \%$ \\
\hline Jetis & 19 & 12 & $63,2 \%$ \\
\hline Kotagede & 53 & 37 & $69,8 \%$ \\
\hline Kraton & 33 & 30 & $90,9 \%$ \\
\hline Mantrijeron & 42 & 27 & $64,3 \%$ \\
\hline Mergangsan & 35 & 19 & $54,3 \%$ \\
\hline Ngampilan & 20 & 16 & $80,0 \%$ \\
\hline Pakualaman & 13 & 10 & $76,9 \%$ \\
\hline Tegalrejo & 33 & 19 & $57,6 \%$ \\
\hline Umbulharjo & 45 & 38 & $84,4 \%$ \\
\hline Wirobrajan & 54 & 44 & $81,5 \%$ \\
\hline Total & 494 & 350 & \\
\hline Rata-rata & & & $70,9 \%$ \\
\hline
\end{tabular}

Sumber: pilkada2017.kpu.go.id/hasil/t2/daerah_istimewa_yogyakarta/kota_ yogyakarta

Persentase pemilih penyandang disabilitas yang menggunakan hak pilihnya sebesar $70,9 \%{ }^{8}$ Kemudian, keterlibatan penyandang disabilitas dalam diskusi politik juga merupakan bentuk partisipasi

8 Rusqiyati, Eka Arifa. 2017. Tingkat Partisipasi Pemilih Yogyakarta Capai Target. Https:// jogja. antaranews. com/ berita/344965/tingkat-partisipasi-pemilih-yogyakarta-capai-target.

Diakses 10 April 2018. 
politik penyandang disabilitas secara konvensional. Selain terlibat aktif dalam sesi diskusi dalam sosialisasi-sosialisasi pilkada kota Yogyakarta 2017, perhelatan pilkada kota Yogyakarta 2017 juga tercatat setidaknya tiga kali penyandang disabilitas dilibatkan dalam diskusi politik. Yang pertama adalah diskusi antara perwakilan lembaga-lembaga yang bergerak di bidang advokasi difabel dengan KPU kota Yogyakarta yang digelar pada 16 November 2016 tentang validasi data pemilih penyandang disabilitas. Diskusi politik yang kedua adalah hadirnya perwakilan lembaga SIGAB dalam diskusi politik oleh KPU kota Yogyakarta yang bertajuk "Jogja Gumregah Menuju Pesta Demokrasi Akuntabel, Transparan, dan Berintegritas” pada 19 Juli 2016 yang salah satunya membahas tentang keterlibatan penyandang disabilitas dalam pilkada kota Yogyakarta 2017. Kemudian, yang ketiga adalah hadirnya perwakilan SIGAB dalam diskusi politik bertema "politik difabel” pada 28 Mei 2016 yang diselenggarakan oleh Universitas Muhammadiyah Yogyakarta dengan mengundang KPU kota Yogyakarta yang memberikan perhatian khusus terhadap kesadaran masyarakat terkait hak politik penyandang disabilitas.

Partisipasi politik penyandang disabilitas juga dapat dilihat dari banyaknya penyandang disabilitas yang tergabung sebagai perwakilan SIGAB, SAPDA, maupun CIQAL. Ketiga lembaga tersebut merupakan kelompok-kelompok kepentingan mewakili kepentingan penyandang disabilitas agar tercipta pilkada kota Yogyakarta yang bersifat inklusi. Selain itu juga dapat dilihat dari bernaungnya aktivis penyandang disabilitas dalam LSM NARASITA sebagai pemantau pilkada kota Yogyakarta 2017.

\section{Metode Penelitian}

Penelitian ini menggunakan metode penelitian yang bersifat deskriptif kualitatif, pembahasan terhadap data dilakukan dengan cara mendeskripsikan analisis yang didapat secara kualitatif, yaitu 
memberikan gambaran tentang masalah yang diteliti. Artinya, deskriptif kualitatif merupakan suatu penelitian yang menggambarkan atau melukiskan suatu peristiwa untuk diambil kesimpulan secara umum, yangmana pada penelitian ini menyangkut pada peningkatan partisipasi politik penyandang disabilitas pada pilkada kota Yogyakarta 2017 dilihat dari faktor determinan atau faktor pendukungnya.

Lokasi yang menjadi tempat penelitian ini berfokus di kota Yogyakarta dan terbatas pada wilayah hukum kota Yogyakarta. Sumber data yang digunakan dalam penelitian ini didapatkan melalui dua sumber data, yaitu data primer dan data sekunder. Data primer diperoleh langsung dari data yang diambil dari stakeholder pilkada kota Yogyakarta 2017 beserta penyandang disabilitas, antara lain KPU kota Yogyakarta, penyandang disabilitas dari unsur NGO SAPDA (Sentra Advokasi Penyandang Disabilitas dan Anak), dan penyandang disabilitas dari unsur KPPD DIY (Komunitas Peduli Pemilu dan Demokrasi-Daerah Istimewa Yogyakarta).

Sedangkan data sekunder adalah data sebagai data pendukung data primer dari literatur dan dokumen serta data yang isinya menyangkut tentang masalah yang bersangkutan dengan penelitian yang dikaji, yang diambil dari KPU kota Yogyakarta dengan data mengenai permasalahan di lapangan yang terdapat pada lokasi penelitian berupa bahan bacaan, bahan pustaka, dan laporan-laporan penelitian. Selain itu, juga diambil dari Komunitas Peduli Pemilu dan Demokrasi DIY dengan data mengenai hasil pemantauan pilkada kota Yogyakarta 2017 dan kabupaten Kulon Progo 2017 yang berupa laporan-laporan pemantauan pilkada yang terjadi di kota Yogyakarta dan kabupaten Kulon Progo tahun 2017.

Teknik analisis data yang dipakai adalah dengan mengonversikan data ke dalam sebuah bentuk yang lebih mudah dipahami dan diinterpretasikan. Analisis data dalam penelitian ini dilakukan 
dengan cara deskriptif kualitatif untuk menganalisa data dengan cara memaparkan dan menafsirkan hasil penelitian dengan susunan katakata dan kalimat sebagai jawaban atas permasalahan yang diteliti. Analisis data yang digunakan dalam penelitian ini bersifat kualitatif, dengan memasukkan data yang kemudian dianalisis dan ditarik sebuah kesimpulan.

\section{Faktor Determinan Peningkatan Partisipasi Politik Penyandang Disabilitas}

Indikator dalam penelitian peningkatan partisipasi politik penyandang disabilitas pada pilkada kota Yogyakarta 2017 dilihat dari faktor pendukung atau faktor determinan memakai teori Milbrath, yaitu perangsang politik, karakteristik pribadi seseorang, karakteristik sosial, situasi atau lingkungan politik, dan pendidikan politik. Faktor perangsang politik adalah faktor dimana suatu dorongan terhadap seorang pemilih agar bersedia berpatisipasi dalam kehidupan politik, yang antara lain adalah keterlibatan penyandang disabilitas dalam diskusi politik dan keaktifan penyandang disabilitas dalam mengakses media massa. Kemudian, faktor karakteristik pribadi seseorang merupakan faktor dari watak sosial seorang pemilih yang mempunyai kepedulian sosial yang besar terhadap berbagai masalah. Karakteristik pribadi penyandang disabilitas tersebut di antaranya rasa kepedulian yang dimiliki serta adanya kemauan untuk terlibat dalam politik.

Selanjutnya, faktor karakteristik sosial yang menggambarkan status sosial, ekonomi, kelompok ras, etnis, dan agama seseorang yang akan memengaruhi persepsi, sikap, perilaku seseorang dalam aktivitas. Dengan kata lain, sikap penyandang disabilitas juga tergantung dari karakteristik sosial seperti status sosial ekonomi, ras dan etnis, dan agama. Kemudian, faktor situasi atau lingkungan politik adalah keadaan lingkungan sosial sekitar seorang pemilih yang baik dan kondusif agar seorang pemilih mau dengan senang hati berpartisipasi dalam aktivitas 
politik. Maka, situasi atau lingkungan politik yang mendukung penyandang disabilitas dalam berpartisipasi adalah situasi lingkungan sekitar yang demokratis dan pengaruh tokoh sekitar. Faktor terakhir yaitu faktor pendidikan politik yang merupakan upaya pemerintah untuk mengubah warga negara agar dapat memiliki kesadaran politik dengan terlibat dalam aktivitas politik. Pendidikan politik di sini dapat dilakukan oleh penyelenggara pemilu, kelompok komunitas, pemerintah melalui kantor Kesbangpol (kantor Kesatuan Bangsa dan Politik), maupun oleh lembaga-lembaga politik.

Dari kelima faktor teori Milbrath tersebut, hasil penelitian menunjukkan bahwa tidak semua faktor memiliki kontribusi dalam peningkatan partisipasi politik penyandang disabilitas pada pilkada kota Yogyakarta 2017. Faktor yang tidak memiliki kontribusi banyak adalah faktor karakteristik sosial yang menyangkut status sosial ekonomi, ras, maupun agama dari penyandang disabilitas yang menggunakan hak pilihnya dalam pilkada kota Yogyakarta. Dilihat dari data penyandang disabilitas di kota Yogyakarta mayoritas beragama Islam, status sosial ekonomi cenderung menengah, dan beretnis Jawa. Agama dan status sosial ekonomi tersebut memang memberi kontribusi sebagai penggerak partisipasi bagi segmen pegiat keagamaan namun tidak signifikan bagi segmen penyandang disabilitas. Sedangkan suku Jawa yang menjadi identitas mayoritas penyandang disabilitas berperan dalam mendorong partisipasi dalam menggunakan hak suaranya untuk memilih dalam pemungutan suara di pilkada kota Yogyakarta 2017, juga tidak signifikan. Adanya budaya atau adat "ewuh pakewuh" memang membuat sebagian kecil penyandang disabilitas yang berasal dari suku Jawa merasa tidak enak atau sungkan jika tidak ikut menggunakan hak pilihnya, namun secara umum penyandang disabilitas lebih digerakkan partisipasinya oleh faktor lain, terutama faktor pendidikan politik dan faktor perangsang politik. 
Faktor determinan yang pertama yaitu faktor perangsang politik yang lebih banyak dikarenakan terselenggaranya diskusi-diskusi politik yang melibatkan penyandang disabilitas. Diskusi-diskusi politik terselenggara pada masa tahapan sebelum tahapan pemungutan suara pilkada kota Yogyakarta 2017 sehingga penyandang disabilitas secara langsung dapat turut serta mencurahkan pendapat juga merasa dilibatkan dalam proses edukasi sebelum pemungutan suara. Diskusidiskusi politik yang terselenggara merupakan bentuk kerja sama antara lembaga penyelenggara pemilu dengan lembaga-lembaga di luar penyelenggara pemilu. Selain diskusi-diskusi politik, faktor determinan perangsang politik juga banyak dipengaruhi oleh keaktifan penyandang disabilitas dalam mengakses media massa.

Dalam diskusi-diskusi politik, lembaga di luar penyelenggara pemilu seperti lembaga perwakilan penyandang disabilitas maupun lembaga yang bergerak di bidang advokasi penyandang disabilitas di kota Yogyakarta diundang dan dilibatkan dalam diskusi. Lembagalembaga perwakilan atau lembaga-lembaga yang bergerak di bidang advokasi penyandang disabilitas yang biasa diundang dan aktif berdiskusi antara lain SIGAB (Sasana Inklusi dan Gerakan Advokasi Difabel), SAPDA (Sentra Advokasi Perempuan Difabel dan Anak), CIQAL (Center for Improving Qualified Activity in Life of People with Disabilities), HWDI (Himpunan Wanita Disabilitas Indonesia), serta GERKATIN (Gerakan untuk Kesejahteraan Tunarungu Indonesia).

Diskusi politik yang pertama yaitu diskusi yang dilaksanakan KPU kota Yogyakarta yang turut serta melibatkan lembaga-lembaga perwakilan penyandang disabilitas maupun lembaga advokasi penyandang disabilitas yang pertama terkait dengan pendataan jumlah penyandang disabilitas untuk dimasukkan dalam daftar pemilih. Diskusi tersebut dilaksanakan untuk memberi kesempatan kepada lembaga-lembaga perwakilan penyandang disabilitas maupun lembaga advokasi penyandang disabilitas untuk mencermati dan memberi 
masukan kepada KPU kota Yogyakarta agar daftar pemilih penyandang disabilitas valid sesuai dengan jenis kedifabelannya. Diskusi tersebut digelar pada 16 November 2016 bertempat di pendopo KPU kota Yogyakarta.

Kemudian diskusi politik kedua yang melibatkan penyandang disabilitas oleh KPU kota Yogyakarta diselenggarakan dengan menggandeng aktivis SIGAB, yaitu M. Joni Yulianto sebagai salah satu pemantik. Diskusi yang bertajuk "Jogja Gumregah Menuju Pesta Demokrasi Akuntabel, Transparan, dan Berintegritas" salah satunya membahas tentang keterlibatan penyandang disabilitas dalam pilkada kota Yogyakarta 2017. Diskusi tersebut juga mengundang lembagalembaga advokasi penyandang disabilitas seperti SIGAB. Diskusi tersebut diinisiasi KPU kota Yogyakarta pada 19 Juli 2016 di Hotel Cavinton Yogyakarta.

Kemudian diskusi politik yang ketiga tentang pilkada kota Yogyakarta 2017 yang melibatkan penyandang disabilitas juga dilakukan oleh Universitas Muhammadiyah Yogyakarta (UMY) tentang politik difabel. Dalam diskusi tersebut, ketua KPU kota Yogyakarta (Wawan Budiyanto) bersama dosen Ilmu Pemerintahan UMY (Tunjung Sulaksono) dan aktivis SIGAB (Ishak Ilham) menjadi narasumber tentang partisipasi pemilih penyandang disabilitas pada pemilu 2014 serta prospek penyandang disabilitas pada pilkada kota Yogyakarta 2017. Diskusi tersebut membahas tentang politik difabel yang memberikan perhatian khusus terhadap kesadaran masyarakat terkait hak politik penyandang disabilitas. Diskusi tersebut diselenggarakan pada 28 Mei 2016 bertempat di ruang sidang Fakultas Hukum UMY.

Kemudian mengenai keaktifan mengakses media massa, banyak penyandang disabilitas yang melek informasi, yaitu aktivis-aktivis penyandang disabilitas yang dapat mengakses media massa dan media sosial. Tidak hanya aktivis yang tergabung dalam SIGAB (Sasana Inklusi 
dan Gerakan Advokasi Difabel), SAPDA (Sentra Advokasi Perempuan Difabel dan Anak), CIQAL (Center for Improving Qualified Activity in Life of People with Disabilities), HWDI (Himpunan Wanita Disabilitas Indonesia), dan GERKATIN (Gerakan untuk Kesejahteraan Tunarungu Indonesia), tetapi juga para penyandang disabilitas yang tidak aktif di lembaga advokasi penyandang disabilitas karena pengaruh kemajuan teknologi seperti penggunaan smartphone yang mempermudah para penyandang disabilitas untuk mengakses media.

Faktor determinan yang paling berperan kedua adalah pendidikan politik. Dengan kata lain, selain faktor perangsang politik, faktor lain seperti faktor pendidikan politik menjadi faktor yang sangat berperan dalam peningkatan partisipasi politik, termasuk partisipasi pemilih penyandang disabilitas. Pendidikan politik yang terselenggara berupa sosialisasi dan pendidikan pemilih kepada penyandang disabilitas merupakan salah satu faktor paling menentukan tentang partisipasi politik karena berhadapan langsung dengan pemilih penyandang disabilitas. Sosialisasi dan pendidikan pemilih kepada penyandang disabilitas dalam pilkada kota Yogyakarta 2017 dilakukan oleh dua kelompok, yaitu kelompok pertama adalah KPU kota Yogyakarta beserta jajarannya dan kelompok kedua adalah komunitas salah satunya adalah KPPD (Komunitas Peduli Pemilu dan Demokrasi) DIY.

Salah satu ketugasan KPU kota Yogyakarta beserta jajarannya seperti PPK (Panitia Pemilihan Kecamatan) di tingkat kecamatan dan PPS (Panitia Pemungutan Suara) di tingkat kelurahan memang memberikan sosialisasi kepada masyarakat luas, tidak terkecuali penyandang disabilitas. Pelaksanaan sosialisasi dan pendidikan pemilih kepada penyandang disabilitas dalam pilkada kota Yogyakarta diampu oleh komisioner KPU kota Yogyakarta divisi sosialisasi, pendidikan pemilih, dan hubungan partisipasi masyarakat (Sri Surani, SP.) Materi sosialisasi dan pendidikan pemilih kepada penyandang disabilitas secara ringkas antara lain tentang definisi pilkada, arti penting pilkada 
secara umum dan bagi penyandang disabilitas, tahapan krusial pilkada, tanggal pemungutan suara, nilai inklusivitas dan pilkada akses, TPS akses dan pelayanan terhadap penyandang disabilitas, ajakan partisipasi dalam pilkada, calon-calon yang berkompetisi, teknis pemungutan suara, tips menjadi pemilih cerdas dan bertanggungjawab, dan tugas setelah pemungutan suara dalam jangka panjang.

Pelaksanaan sosialisasi dan pendidikan pemilih kepada penyandang disabilitas salah satunya adalah pelaksanaan sosialisasi yang dilanjutkan dengan simulasi pemungutan suara secara serentak di 14 titik berbasis kecamatan yang juga melibatkan PPK dan PPS di wilayah kecamatan masing-masing. PPK dan PPS di masing-masing wilayah kecamatan menggelar sosialisasi dan simulasi pemungutan suara, khusus bagi penyandang disabilitas dilaksanakan pada 11 Februari 2017 pukul 10.00-12.00 WIB. Sosialisasi dan pendidikan pemilih yang terkait dengan penyandang disabilitas juga dilakukan melalui media elektronik. Salah satunya bertema "Seputar Pilwali Jogja 2017" pada program Langen Swara-Jogja TV pada 16 Januari 2017, dengan pembicara Pangky Febriantanto, S.IP selaku PPK Wirobrajan kota Yogyakarta. Kemudian, bertema "Difabel dalam Pillada" pada Program Bincang Siang-RRI Pro 1 Jogja pada 04 Februari 2017, dengan pembicara Pangky Febriantanto, S.IP dan Widi Haryanti. Hal-hal yang disampaikan adalah mengenai pentingnya pemilu akses bagi penyandang disabilitas, partisipasi penyandang disabilitas dalam pemilu, serta nilai-nilai inklusi dalam pilkada kota Yogyakarta 2017.

Pendidikan pemilih kepada penyandang disabilitas yang dilakukan oleh KPPD (Komunitas Peduli Pemilu dan Demokrasi) juga dilakukan, baik bekerja sama dengan KPU kota Yogyakarta maupun secara mandiri. Pendidikan pemilih yang dilakukan dengan bekerja sama dengan KPU kota Yogyakarta dilaksanakan pada 24 Januari 2017 bertempat di pendopo kantor KPU KOTA Yogyakarta dari pukul 09.00-13.00 WIB, didampingi oleh dua orang penerjemah bahasa isyarat atau interpreter 
dengan materi demokrasi dan pemilu, hak penyandang disabilitas, pemilu akses, dan partisipasi.

Pendidikan pemilih yang kedua dilaksanakan pada 05 Februari 2017 bertempat di sekretariat Gerkatin (Gerakan untuk Kesejahteraan Tuna Rungu Indonesia) DPD DIY dari pukul 14.00-16.00 WIB dengan materi demokrasi, pemilu, dan pemilu akses. Pemateri dari kegiatan tersebut adalah komunitas Peduli Pemilu dan Demokrasi DIY yang didampingi dua orang interpreter (penerjemah dengan bahasa isyarat) dari komunitas Peduli Pemilu dan Demokrasi DIY juga.

Faktor karakteristik pribadi yang menurut Milbrath merupakan salah satu faktor pendukung dalam partisipasi politik memang terbukti, namun tidak sebesar perangsang politik dan pendidikan politik. Karakteristik pribadi penyandang disabilitas yang memiliki rasa kepedulian terhadap isu-isu difabel serta kemauan terlibat dalam kegiatan politik juga memengaruhi partisipasi politik penyandang disabilitas dalam pilkada kota Yogyakarta 2017. Hal itu dikarenakan sesama penyandang disabilitas memiliki rasa kebersamaan dalam memperjuangkan hak-hak penyandang disabilitas, termasuk hak dalam politik seperti pemilu. Selain itu, karakteristik penyandang disabilitas yang aktif juga terdorong selain dari pengaruh aktivis penyandang disabilitas, juga dikarenakan adanya berbagai pelatihan maupun edukasi yang berkaitan dengan advokasi bagi penyandang disabilitas.

Gambaran karakteristik penyandang disabilitas salah satunya tercermin dari kemauan aktivis penyandang disabilitas dalam kegiatan politik diskusi serta aktif memberikan tanggapan pada diskusi antara lembaga advokasi penyandang disabilitas dengan KPU kota Yogyakarta pada 16 November 2016 di pendopo kantor KPU kota Yogyakarta dan juga keaktifan M. Joni Yulianto selaku penyandang disabilitas dalam memantik diskusi pada 19 Juli 2016. Bahkan, M. Joni Yulianto merupakan motivator yang sudah terkenal di kalangan penyandang 
disabilitas.

Selain itu, terdapat kepedulian terhadap isu-isu yang menyangkut kedisabilitasan dalam kepemiluan termasuk dalam pilkada kota Yogyakarta 2017 yang memang berdampak serta berpengaruh terhadap nasib penyandang disabilitas, baik langsung maupun tidak langsung. Hal itu menjadi salah satu aspek determinan dalam peningkatan partisipasi politik, termasuk partisipasi pemilih penyandang disabilitas. Contohnya adalah isu mengenai peraturan daerah tentang inklusivitas dan tentang disabilitas yang diusung oleh seluruh calon yang berkompetisi dalam pilkada kota Yogyakarta 2017. Dengan kata lain, peraturan daerah atau kebijakan yang menyangkut nasib penyandang disabilitas nantinya sedikit banyak dipengaruhi oleh kebijakan publik yang diambil oleh pemimpin daerah, dan pemimpin daerah adalah orang-orang yang dipilih saat pemilihan kepala daerah atau pilkada. Kesadaran akan pentingnya pilkada bagi penyandang disabilitas tersebut juga didukung oleh motivasi penyandang disabilitas untuk tahu mengenai hak difabel dalam pilkada, termasuk pelayanan khusus yang didapat oleh pemilih penyandang disabilitas seperti TPS yang dapat diakses dan ramah difabel serta pelayanan petugas KPPS yang benar dalam melayani pemilih penyandang disabilitas sesuai jenis kedifabelannya.

Karakteristikyangpedulijuga tercermin darikemauan sertakerelaan banyak penyandang disabilitas untuk terlibat dalam pemantauan di setiap tahapan pilkada, sehingga dapat meminimalisir pelanggaranpelanggaran termasuk salah satunya tahapan pemutakhiran data pemilih tentang valid tidaknya data pemilih penyandang disabilitas yang masuk dalam daftar pemilih. Kemauan penyandang disabilitas juga dipengaruhi oleh adanya rasa panggilan jiwa tanpa diberi honor sama sekali untuk turut terlibat dalam suatu ajang perhelatan demokrasi yang membuktikan bahwa keterbatasan bukan halangan untuk turut menyukseskan perhelatan pesta demokrasi. Salah satu contohnya 
adalah beberapa penyandang disabilitas secara resmi terdaftar sebagai petugas pemantau pilkada 2017 yang bernaung di bawah perkumpulan NARASITA untuk memantau pelaksanaan pilkada kota Yogyakarta 2017 dan pilkada kabupaten Kulon Progo 2017.

Sama halnya dengan faktor karakteristik pribadi, faktor situasi atau lingkungan politik juga merupakan salah satu faktor pendukung dalam partisipasi politik. Meski demikian, faktor situasi atau lingkungan politik tidak memiliki peran sebesar perangsang politik dan pendidikan politik. Faktor situasi atau lingkungan politik yang berperan dalam partisipasi politik penyandang disabilitas dalam pilkada kota Yogyakarta 2017 di antaranya karena dukungan lingkungan yang demokratis dalam kehidupan penyandang disabilitas serta adanya tokoh-tokoh penyandang disabilitas yang akhirnya menjadi panutan di lingkungan penyandang disabilitas.

Kota Yogyakarta pada khususnya dan Indonesia pada umumnya merupakan lingkungan yang demokratis, setiap warga negaranya termasuk penyandang disabilitas diberi kebebasan untuk menentukan suaranya. Hal itu juga terlihat dalam diskusi yang diselenggarakan oleh KPU kota Yogyakarta pada 16 November 2016 yang memberi ruang berekspresi dan ruang berpendapat kepada penyandang disabilitas tentang salah satu hal yang krusial dalam pilkada, yaitu daftar pemilih. Dengan demikian, penyandang disabilitas dapat nyaman dan merasa diberi tempat untuk menentukan hak politiknya.

Selain itu, ada pengaruh tokoh-tokoh penyandang disabilitas yang aktif memperjuangkan isu-isu yang berkaitan dengan penyandang disabilitas dalam pemilu secara umum dan pilkada secara khusus. Tokoh pertama adalah M. Joni Yulianto, aktivis SIGAB yang sering mengisi materi seputar kesetaraan penyandang disabilitas dengan yang bukan penyandang disabilitas. M. Joni Yulianto termasuk seorang difabel netra yang lama bergelut di dunia advokasi penyandang 
disabilitas, termasuk dalam gelaran pemilu secara umum dan pemilihan kepala daerah secara khusus, terutama tentang pelayanan terhadap penyandang disabilitas dan tentang fasilitas yang diberikan kepada penyandang disabilitas agar pemilih penyandang disabilitas dapat dilayani sesuai dengan jenis kedifabelannya.

Tokoh kedua adalah Widi Haryanti, mantan aktivis SIGAB yang sering memberi edukasi ke sesama teman-teman penyandang disabilitas tentang demokrasi dan hak penyandang disabilitas dalam pesta demokrasi seperti pilkada. Widi Haryanti juga terlibat aktif sebagai penyelenggara pemilu, seperti KPPS (Kelompok Penyelenggara Pemungutan Suara) dan aktif dalam KPPD (Komunitas Peduli Pemilu dan Demokrasi) DIY untuk memberi pendidikan politik dan pendidikan pemilih. Widi Haryanti juga terkenal di kalangan penyandang disabilitas karena sering menyuarakan dan memperjuangkan terciptanya pemilu akses bagi pemilih penyandang disabilitas.

\section{Kesimpulan}

Dari pembahasan tersebut, maka dapat ditarik kesimpulan bahwa dari lima faktor pendukung dalam partisipasi politik menurut Milbrath, hanya ada satu faktor, yaitu faktor karakteristik sosial yang tidak memiliki peran dalam peningkatan partisipasi politik penyandang disabilitas dalam pilkada kota Yogyakarta 2017. Sedangkan faktor perangsang politik dan faktor pendidikan politik merupakan faktor paling determinan dalam peningkatan partisipasi politik penyandang disabilitas pada pilkada kota Yogyakarta 2017. Faktor perangsang politik dapat dilihat dari pelibatan kelompok penyandang disabilitas dalam diskusi politik tentang pilkada kota Yogyakarta 2017 serta pelibatan dalam setiap tahapan pilkada kota Yogyakarta 2017, terutama tahapan daftar pemilih. Sedangkan faktor pendidikan politik dapat dilihat dari dengan terlaksananya sosialisasi dan pendidikan pemilih, baik yang dilakukan oleh penyelenggara pilkada kota Yogyakarta, yaitu 
KPU Kota Yogyakarta maupun lembaga lain, seperti Kominitas Peduli Pemilu dan Demokrasi yang merupakan komunitas nondifabel yang menggandeng Gerkatin yang merupakan komunitas difabel.

Meskipun tidak sebesar faktor perangsang politik dan faktor pendidikan politik, tetapi faktor karakteristik pribadi dan faktor lingkungan atau situasi politik juga menjadi faktor determinan dalam peningkatan partisipasi politik penyandang disabilitas pada pilkada kota Yogyakarta 2017. Faktor karakteristik penyandang disabilitas dapat dilihat dari tingginya motivasi penyandang disabilitas untuk berperan dalam pilkada serta adanya kesadaran akan pentingnya pilkada bagi penyandang disabilitas. Sedangkan faktor lingkungan atau situasi politik dapat dilihat dari keaktifan para penyandang disabilitas dalam mengikuti diskusi-diskusi politik serta motivasi dari para tokoh penyandang disabilitas, seperti M. Joni Yulianto dan Widi Haryanti. 


\section{Referensi}

Amirudin dan A. Zaini Bisri. (2006). Pilkada Langsung, Problem dan Prospek, Sketsa Singkat Perjalanan Pilkada 2005. Yogyakarta: Pustaka Pelajar.

Budiarjo, Miriam. (1998). Partisipasi dan Partai Politik. Jakarta: Yayasan Obar Indonesia.

Dahl, A. Robert. (2001). Perihal Demokrasi. Jakarta: Yayasan Obor Indonesia.

Disabled World. (T.T) Definitions of Disability. Http://disabledworld. com/definitions/ disability-definitions.php. Diakses pada 10 April 2018.

Efrizal. (2012). Political Explore Sebuah Kajian Ilmu Politik. Bandung: Alfabeta.

Firmanzah. (2008). Marketing Politik Antara Pemahaman dan Realitas, Edisi Kedua. Jakarta: Yayasan Obor Indonesia.

General Election Network For Disability Acces. (2017). Sekilas Tentang Disabilitas. Http://agendaasia.org/index.php/id/informasi/ sekilas-tentang-disabilitas/102-seki las-tentang-disabilitas. Diakses pada 10 April 2018.

Lasida, I Gusti Gede Made Gustem. (2017). “Membangun Pemilu Inklusif untuk Difabel dengan Studi Kasus Pilwali Kota Yogyakarta 2017”. Tesis. Surabaya: Universitas Airlangga.

Maran, Rafael Raga. (2007). Pengantar Sosiologi Politik. Jakarta: Rineka Cipta.

Masoed, Mochtar. (2011). Perbandingan Sistem Politik. Yogyakarta: Gadjah Mada University Press. 
Nawawi, Hadari, (2001). Metode Penelitian Bidang Sosial. Yogyakarta: Gadjah Mada University Press.

Nelson, Joan dan Samuel P. Huntington. (1990). Partisipasi Politik di Negara Berkembang. Jakarta: Rineka Cipta.

Oppyfia, Metty Sinta. (2017). “Pemenuhan Hak Politik Difabel Pilkada Kota Yogyakarta Tahun 2017 (Studi Implementasi UU No. 8 Tahun 2016)". Skripsi. Yogyakarta: UIN Sunan Kalijaga.

Peter, Coleridge. (2007). Pembebasan dan Pembangunan Perjuangan Penyandang Cacat di Negara-Negara Berkembang. Yogyakarta: Pustaka Pelajar.

Pito, Toni Adrianus dkk. (2006). Mengenal Teori-Teori Politik dari Sistem Politik Sampai Korupsi. Bandung: Penerbit Nuansa.

Putra, Agus Andika. (2015). “Tingkat Partisipasi Penyandang Disabilitas pada Pemilu 2014 di Kota Yogyakarta”. Skripsi. Yogyakarta: Universitas Muhammadiyah Yogyakarta

Rahman, Arifin. (2002). Sistem Politik Indonesia dalam Perspektif Struktural Fungsional. Surabaya: SIC.

Rusqiyati, Eka Arifa. (2017). Tingkat Partisipasi Pemilih Yogyakarta Capai Target. jogja.antaranews.com/berita/344965/tingkatpartisipasi-pemilih-yogyakarta-capai -target. Diakses pada 10 April 2018.

Ruslan, Rosady. (2005). Manajemen Public Relations \& Media komunikasi. Jakarta: Raja Grafindo Persada.

Sastroatmodjo, Sudijono. (1995). Perilaku Politik. Semarang: IKIP Semarang Press

Soekanto, Soerjono. (2010). Sosiologi Suatu Pengantar. Jakarta: Rajawali Pers. 
T.N. (2017). Persentase Pengguna Hak Pilih Penyandang Disabilitas Pilkada Kota Yogyakarta 2017. Http://pilkada2017.kpu.go.id/ hasil/t2/daerah_istimewa_yogya karta/kota_yogya-karta. Diakses pada 10 April 2018.

Vash, C. L. (1981). The Psychology of Disability. New York: Springer Publishing Company. 